\title{
THE ASSIGNMENT OF LIFE INSURANCE AS COLLATERAL SECURITY FOR BANK LOANS
}

Not until the depression of the '30's was the investment function of life insurance thoroughly exploited. ${ }^{1}$ With the loss in value of customary forms of collateral such as stocks and bonds, many borrovers found their life insurance the only substantial asset still available to them, ${ }^{2}$ and for the first time large amounts of life insurance were pledged as collateral security for bank loans. ${ }^{3}$ Although entitled to borrow from the insurer, the policyholder found the bank rate of interest much lower than the six per cent company charge." In addition, more capital could be obtained from a bank loan based on the policy's face value ${ }^{5}$ than from a policy loan or cash surrender, which were both limited by the reserve value of the policy. ${ }^{\circ}$ And banks as a whole were quick to realize the potentialities of this collateral because of its unfluctuating and readily liquid value. ${ }^{7}$

Although life insurance has become a medium for investment as well as the beneficiary's security, it was originally conceived solely to provide pro-

1. "The depression of the 1930's is supplying the first prolonged test of the guaranteed cash and loan provisions of life insurance policies. True, the relatively short panics of 1907-8 and 1920-1 did markedly step up the demand for cash and loan values. But in comparison with what has happened in the last three years they were passing showers. Since October, 1929, the rains have descended and the floods have come . .." Linton, Panics and Cash $V$ alues, 33 Transactions of the Actuarma Soc. of Asr. 365 (1932); Tatt, Assignarent of Life Insuraxce Policies as Colraternl Secunity 1 (1939).

For a comprehensive analysis of the investment aspect of present-day life insurance policies, see Timberg, Insurance and Intcrstate Commerce, 50 YALE L.J. 959, 978 et seq. (1941).

2. Holland, Life Insurance as Collateral 1 (1937) (pamphlet published by Phoenix: Mutual Life Insurance Company of Hartford, Conn.).

3. Stanley, Life Insurance as Collateral, 127 Burrkers' AlıG. 237 (1937); sce Davis v. Modern Industrial Bank, 279 N.Y. 405, 413, 18 N.E.2d 639, 642 (1939).

4. TAIT, op. cit. supra note 1 , at 1 .

5. Although if presently liquidated the policy may be worth less than the face value, banks will often lend up to the face value if they feel that they can depend on the borrower to maintain premium payments.

6. Since underwriting and other expenses are usually charged off against the initial premium payments, the reserve value of the policy is usually quite small for the first few years. For an analysis of the various deductions made, see $T$ he $W h y$ and $W$ herefore of Surrender Values, The Bankers', INs. Mgrs.' \& Agents' MIAG. 311 (Oct. 194\$).

7. Collins, Collateral Assigmments from the Vienpoint of the Lender, Procendras, Axr. Bar Ass'n, SEct. of Ins. LAw 91 (1936).

Until the ' 30 's banks generally considered life insurance an undesirable collateral for loans. See Excerpts from Banker's Correspondence-Life Instrance as Collalcral, 21 Ali. Bankers Ass's J. 863 (1929). But see Sorenson, Life Insturanee Policies as Collateral to Bank Loans, 21 Axr. BANKERs Ass'2r J. 1040 (1929). Some banlis still hesitate to loan money on life insurance because they do not wish to place in jeopardy the last vestige of the borrower's security. Others feel that there is too much red tape and uncertainty connected with a loan on this type of collateral. And some of the larger metropolitan banks have not gone extensively into this field because of the fact that their 
tection in case of death. ${ }^{8}$ Since policies taken out in the last century provided only for death benefits and there was no way in which to change the beneficiary, the insured had no control over the policy.9 However, with the development of legal reserve life insurance, surrender values became available to the insured, ${ }^{10}$ first simply as company practice, then by provisions in the policy, and later, in many states, by statute. ${ }^{11}$ Present day policies, while still primarily oriented towards providing a fund at maturity, give the insured many important benefits in the form of options to surrender the policy for its cash value, to procure cash loans, and to obtain loans to pay premiums. ${ }^{12}$ Usually included, too, is a procedure for changing the beneficiary and assigning the policy. ${ }^{13}$ Indeed a much-emphasized selling point of life insurance is the facility with which it can be turned into cash to meet emergencies. ${ }^{14}$

Increased resort to the investment function has given rise to two trouble. some problems relating to the assignment of life insurance as collateral. ${ }^{1_{5}}$

directors are on the boards of insurance companies and they do not wish to place the bank in the position of lending money on policies at a rate of interest less than that at which insurers lend money to their policyholders. Webster, Collateral Assignments from the Viewpoint of the Insured, ProceEdrngs, AM. BAR Ass'N, SECT. OF INs. LAw 78 (1936).

8. See Burlingham v. Crouse, 228 U.S. 459, 472 (1913); Webster, supra note 7, at 79.

9. See Dechert, Assignments of Life Insurance Policies, contained in McCaInnN, Tue Beneficiary IN Life Insurance 22 (1948); TAIT, op. cit. supra note 1, at 23. Even one who procured a policy of insurance upon his own life, payable to his legal heirs, atthough he paid the premiums himself and kept the policy in his exclusive possession, could not change the beneficiary when the policy did not so provide. Yore v. Booth, 110 Ca1. 238, 42 Pac. 808 (1895).

10. Mowbrax, Insurance 152-3 (1937).

11. Provision for a cash surrender value was first made in the Massachusetts laws in 1880. Mass. Laws 1880, c. 232. For a modern statute, see, e.g., N.Y.INs. LAw \& 208.

12. See Commissioner v. Illinois Life Ins. Co., 80 F.2d 280, 282 (7th Cir. 1935).

13. Although life insurance was not assignable at common law due to the prohibition against assigning choses-in-action, 2 WILLIston, Contracts $\$ 405$ (1936), in the light of modern judicial decisions it is now freely assignable, as are all other choses-in-action, in the absence of statutory barriers or prohibiting provisions in the policy. Moon v. Williams, 102 Fla. 214, 135 So. 555 (1931); Andrews v. Bankers' Life Ins. Co., 214 Ia. 573, 240 N.W. 215 (1932). Most modern policies have been drafted on this assumption and merely include a provision stating that to be effective a copy of the assignment must be filed with the company, or that it must be in writing on the company's form. Mownray, op. cit. supra note 10, at 172 .

If an assignment is made by the insured as security for an existing or contemporaneously incurred indebtedness, there is never any question of complying with the requirement of insurable interest. Brown v. Greenfield Life Ass'n, 172 Mass. 498, 53 N.E. 129 (1899); 6 Couch, Cyclopedia of Insurance Law 5248 (1930). Sec Watson v. Massachusetts Mutual Life Ins. Co., 140 F.2d 673 (D.C. Cir. 1943).

14. Linton, supra note 1 , at 365 .

15. The troublesome nature of these problems is attested to by the plethora of articles on the subject in banking journals. See, e.g., Ludlow, Life Insurance Loans, 35 BANKw140 50 (Feb., 1943); McKinnon, Life Insurance Policies as Collateral, 29 Bunkina 
The first is whether the insured himself can defeat the beneficiary's interest by an assignment. If he is given a free hand in assigning his insurance, the investment possibilities are enhanced. Most courts have allowed this inroad on the beneficiary's erstwhile inviolability, but courts in a substantial number of jurisdictions, imbued with the sanctity of the beneficiary's rights, still make every effort to limit the insured's ability to capitalize his policies, and succeed at least in contributing uncertainty to this area of insurance law. ${ }^{16}$

The second problem concerns the extent of control over the policy which will be allowed to the bank-assignee. Clearly, if the insured defaults, the bank should not only have a claim to the proceeds of the policy at maturity, ${ }^{17}$ but should be able to liquidate the policy by means of the cash surrender option. ${ }^{18}$ Furthermore, the bank should be able to keep the borrower from diminishing the policy's cash value. ${ }^{19}$ But should it be given absolute control over all the options which are conferred on the insured? Life insurance is a special form of collateral. If cancelled, it is often irreplaceable ${ }^{20}$ and, if the insured is in failing health, a policy's actual value may be more than the amount it will bring on liquidation. ${ }^{21}$ Therefore, although realizing the necessity of safeguarding the bank, courts and insurers have continually sought ways in which to protect the dormant security aspect of an assigned policy.

Solution of these problems is complicated for they involve adjustment of three conflicting interests-those of the insured, the beneficiary, and the bank. ${ }^{22}$ However, by means of close cooperation between banks and insurers, and with increasing judicial cognizance of the dual nature of life insurance, the areas of uncertainty surrounding the collateral assignment of life insurance are being steadily diminished.

82 (Feb., 1937) ; Loell, Life Insurance as Supporting Collateral, 27 Bawwng 90 (Oct, 1934); Tait, Collateral Loais on Life Insurance, 140 Basirezs' ALac. 292 (1940); Goldin, Insurance Assignanents to Bankcrs, 134 BuNkens' MLıG. 309 (1937) ; Smith, Assets Revealed in Insurance Cash Values, 129 Bawnens' M1Ag. 471 (1934).

16. "The cases involving this question have fallen into the greatest confusion, due in part to the great variation in the language of the policies and fact situations involved, and partly to the failure of some courts to keep in mind the origin and paculiar nature of the beneficiary's right." VANCE, INSURANCE 562 (2d ed. 1930).

17. Taylor v. Southern Bank \& Trust Co., 227 Ala. 565, 151 So. 357 (1933).

18. See Note, 48 Yale L.J. 315 (1938). See p. 756 infro.

19. See p. 759 infra.

20. This depends on such factors as the age and health of the insured. Sce Conments on Form No. 10-Assignment of Life Insurance as Collateral (1941) (pamphlet published by Bank Mianagement Commission, American Bankers Association).

21. I.e., the face value of the policy minus the amount the insured will have to gay in premiums before his death may exceed the surrender value. This is particularly true if the policy has not been in force very long. See note 6 supra for method in which surrender value is computed.

22. There is really a fourth interest, also-that of the insurance company. It must make the initial interpretation of the validity and effect of the various assignment forms with which it is presented and, in doing so, often acts at its peril. Handy, Colloferal As- 


\section{The Right of the Insured to Assign His Life Insurance}

If no beneficiary is named and the proceeds are made payable to the insured's estate, then there is no doubt that the beneficial rights are all in the insured and that he can make an effective assignment himself. ${ }^{23}$ Similarly, there is no doubt if by the terms of the policy the beneficiary's interest is subordinated to that of an assignee. ${ }^{24}$ But most policies in force today fall into neither of these two categories and it is often uncertain in whom the right to assign resides as between the insured and the beneficiary.

This uncertainty is the result of the lingering effect of rules of law created with reference to older policies issued in the United States which vested absolute control in the beneficiary. Typically in these policies, the beneficiary could not be changed; the insured might pay the premiums but had no rights at all. ${ }^{25}$ When the extent of the beneficiary's control was fully realized, insurance companies began including clauses in the insurance contract which made the designation of the beneficiary revocable at the will of the insured. ${ }^{26}$ But courts could not agree as to whether this insertion transferred control to the insured or whether control remained in the beneficiary subject to removal only by a change of beneficiary executed in the exact manner outlined in the policy. Under the first premise, the insured can make an effective assignment directly, but under the other the beneficiary must either consent or be displaced.

\section{Where No Right to Change the Beneficiary Is Reserved}

Where a policy contains no provision for a change of beneficiary, it may be assigned as collateral only if the beneficiary joins in the assignment. ${ }^{27}$ This results from almost unanimous holdings that the beneficiary in a policy of this type has a "vested interest" in the proceeds the moment it is issued. 2 a

sigmnents from the Viezupoint of the Insurer, PROCEEDINGS, AM. BAR Ass'N, SECT, or INS. LAw 85 (1936); see New York Life Ins. Co. v. Rees, 19 F.2d 781 (8th Cir. 1926).

23. Oleska v. Kotur, 113 Ind. App. 428,48 N.E.2d 88 (1943); Abbruzise v. Sposata. 306 Mass. 151, 27 N.E.2d 722 (1940); 2 Cooley, Briefs on Insurance 1804 (2d ed. 1927).

24. Fisher \& Co. v. Phoenix Mutual Life Ins. Co., 15 Tenn. App. 502 (1932). Sec p. 753 infra.

25. See Douglass v. Equitable Life Assur. Soc., 150 La. 519, 90 So. 834 (1922); VANCE, INSURANCE, 548 (2d ed. 1930).

26. Vance, The Beneficiary in Life Insurance, 31 YaLe L.J. 343, 358 (1922).

27. Jackson Bank v. Williams, 77 Miss. 398, 26 So. 965 (1899); Couc1, op. cit. supra note 13 , at 5232 .

28. Washington Central Bank v. Hume, 128 U.S. 195 (1888); cases collected in 29 AMr.Jur. 950 n.11.

Wisconsin alone holds the opposite view, allowing the insured to defeat the beneficiary's interest by surrender or assignment. Clark v. Durand, 12 Wis. 223 (1860); Opitz v. Karel, 118 Wis. 527, 95 N.W. 948 (1903). However, by statute, the prevailing rule is applicable even in that state where the beneficiary is the wife of the insured. Boehmer v. Kalk, 155 Wis. 156, 144 N.W. 182 (1913). 
An interest thus characterized cannot be defeated by any action of the insured to which the beneficiary does not consent, ${ }^{3}$ unless some right is specifically reserved in the policy. ${ }^{\text {io }}$

The creation of a "vested" right in the beneficiary is peculiar to American jurisprudence. In virtually every other country the insured retains complete control over the contract and can assign or surrender it as he sees fit. ${ }^{31}$ The reason for the aberrational American rule is not entirely clear. ${ }^{32}$ IYhile the status of third party beneficiaries in contract law had been recognized by some courts in the United States ${ }^{33}$ when the "vested interest" rule was being developed, the third party beneficiary doctrine does not compel the conclusion that the beneficiary's rights are irrevocable. ${ }^{34}$ This is substantiated by the fact that the "vested interest" rule is only applied to regular life insurance policies and not to certificates of mutual benefit associations. ${ }^{35}$

The most rewarding sources for the motivation behind this rule are early

29. Preston v. Connecticut Mut. Life Ins. Co., 95 MId. 101, 51 Atl. 838 (1902); Lacl:wood v. Michigan Mit. Life Ins. Co., 10S Mich, 334, 66 N.W. 229 (1S96).

To preserve his interest, a beneficiary may pay the premiums if the insured does not. Langford v. National Life Ins. Co., 116 Ark. 527, 173 S.WV. 414 (1915).

30. Thus the insured is allowed to recover the cash surrender value, Schuberth v. Prudential Ins. Co. of America, 86 Pa. Super. 80 (1925); and may be entitled to a policy loan, Eagle v. New York Life Ins. Co., 48 Ind. App. 284, 91 N.E. 814 (1910).

31. In England the designation of a beneficiary implies no rights whatever before the death of the insured. See Cleaver v. Miutual Reserve Fund Life Ass'n [1S92] 1 Q.B. 147,152 . However, the Statute of $1882,45 \& 46$ Vrct., c. 75 , $\$ 11$, did create a trust in favor of a wife or children named as beneficiaries.

In France the beneficiary's interest is revocable at any time beiore acceptance by the beneficiary, but irrevocable afterwards. 2 FuzIer-Heraran, Conz Crum Arizore 986-98 (1896).

32. Vance, supra note 26 , at 347.

33. E.g., Lawrence v. Fox, 20 N.Y. 268 (1859).

34. Although the general rule today is that a donee beneficiary acquires an indefeasible right on the making of the contract, there is case support for the opposite position. Plott v. Kittelson, 58 N.D. 881, 228 N.W. 217 (1929) ; cf. People's Bank \& Trust Co. v. Wcidinger, 73 N.J.L. 433, 64 Atl. 179 (1906). In the landmark case of Lawrence v. Fox, 20 N.Y. 268 (1859), Justice Gray was in doubt as to whether the promisee could have released the promisor. Id. at 274. However, this case involved a creditor benefieiary.

According to Professor Vance, the third party beneficiary concept ". . . by no means necessitates the conclusion that the designation of a person as beneficiary of a conditional promise to pay money at a future date gives that person a vested right in the promise. It is wholly a question of the promisee's intent. He may intend to retain entire control over the benefit of the promise until his death and that the beneficiary shall talie nothing until that event, or that the beneficiary shall assume a present right to demand in future performance of the promisor, reserving to himself, however, the power to estinguish that right at will, or he may intend to make an irrevocable gift by way of declaration of trust. In the case of insurance contracts this intent may be clearly expressed, as where an express trust in favor of the beneficiary is declared, but it is usually necessary to determine it by implication from the words of the contract taken in connection with the circumstances under which it was made." Vance, supra note 26 , at $349-9$.

35. Supreme Council of Royal Arcanum v. Behrend, 247 U.S. 394 (1918); Lahey v. Lahey, 174 N.Y. 146, 66 N.E. 670 (1903) ; 7 CCoLEY, op. cit. supra note 23, at 6416. 
state statutes designed to protect beneficiaries. For instance, in 1840 the New York legislature enacted a statute authorizing a married woman in her own name to insure the life of her husband; ${ }^{30}$ and the proceeds of such a policy were protected from attachment by her husband's creditors so long as the premiums did not exceed three hundred dollars. ${ }^{37}$ The Massachusetts legislature went even farther in an 1844 statute which made the proceeds of a policy taken out for the benefit of a married woman by any person on any life inure to her "separate use and benefit and that of her children, if any, independently of her husband and of his creditors." ${ }^{38}$ It also provided that the proceeds of a policy payable to another than the one procuring it: should be payable to the named beneficiary free from the claims of creditors of the person effecting the insurance. Thus buttressed by a clear statutory intent to safeguard the beneficiary from creditors, courts were not reluctant to go one step further and protect the beneficiary from the insured himself. ${ }^{85}$

\section{When the Right to Change the Beneficiary Is Reserved}

Since the effects of the "vested interest" rule contravened the insured's actual intent in most cases, ${ }^{40}$ insurance companies inserted in their policies a

36. N.Y. Laws 1840 , c. 80 . Similar statutes were passed in Connecticut (1850), New Hampshire (1850), and Minnesota (1851). Provisions to this effect were also included in the legislative charters of several insurance companies. See CharTers and BY-LAw of THIRTY-FIVE LIFE INSURANCE CoMpanies (Flitcraft, 1896).

37. See Eadie v. Slimmon, 26 N.Y. 9, 17 (1862), for a discussion of this statute.

38. Mass. Laws 1844, c. 82 .

39. The unique nature of this doctrine is matched by a unique history. Prior to 1872 no commentator had mentioned the problem as to the nature of the beneficiary's right. In that year, however, Bliss in his treatise on insurance made the following statement: "We apprehend the general rule to be that a policy, and the money to become due under it, belong the moment it is issued to the person or persons named in it as the beneficiary or beneficiaries, and that there is no power in the person procuring the insurance by any act of his, or hers, by deed or by will, to transfer to any other person the interest of the person named. The person designated in the policy is the proper person to receipt for and to sue for the money. The legal representatives of the insured have no claim upon the money and cannot maintain an action therefore, if it is expressed to be for the benefit of someone else." Buiss, Insurance 496 (1872). To support this broad asseveration, Bliss could cite but one case, McCord v. Noyes, 3 Bradf. 139 (N.Y.Surr. Ct. 1855) and that does not appear to substantiate his text. Yet in 1888 the Supreme Court adopted this statement of the law word for word (neglecting the use of quotes and without citing Bliss). Washington Central Bank v. Hume, 128 U.S. 195, 206 (1888). And with the exception of Wisconsin (see note 28 supra) the rest of the courts in the Unitcd States quickly followed suit.

40. For example, the beneficiary's interest is not defeated by a divorce from the insured nor by termination of any other relation that may have induced the procurement of the policy. Filley v. Illinois Life Ins. Co., $91 \mathrm{Kan} .220,137$ Pac. 793 (1914). Morcover, it is the prevailing rule that when the beneficiary's interest is vested, the beneficiary can transfer it even before the insured's death by assignment or by will. Harvey v, Van Cott, 71 Hun. 394, 25 N.Y. Supp. 25 (1893). And in the absence of exemption statutes, it can be seized by the beneficiary's creditors for his debts. Amberg v. Manhattan Life Ins. Co., 171 N.Y. 314, 63 N.E. 1111 (1902). 
clause which enabled the insured to reserve the right to change the beneficiary. ${ }^{41}$

Because of the addition of this clause, most courts now construe an election of the right to mean that the insured wishes to retain the beneficial ownership of the policy during his lifetime.42 Instead of having a "vested right," the beneficiary now has nothing more than an "expectancy." is This view is given added impetus by the development" of the various surrender options which effectively give the policyholder control over the cash reserve during his lifetime. The security function is subordinated until the insured's control is extinguished by death. ${ }^{41}$ Thus conceived, it follows that the insured can assign and the assignee receive an interest in the proceeds superior to that of the named beneficiary. ${ }^{45}$

Several other rationalizations have been developed for giving the insured a free hand in assigning his life insurance. Since the insured unquestionably could defeat the beneficiary's interest in a roundabout way by first changing the beneficiary to his own estate, there seems no reason to prohibit him from accomplishing the same result directly by assigning the policy." And a few courts have allowed unrestricted assignability on the theory that the bare act of assignment is equivalent to the appointment of a new beneficiary. ${ }^{47}$ The bank is only allowed to take to the extent of its interest,

41. VANCE, op. cit. supra note 16 , at 560 .

42. "As the policy to Swett stipulated that he might, on his written request of the company for its appropriate indorsement on the policy, change the beneficiary, his wife did not acquire a permanent or vested interest in it. The existence of such an interest during her husband's lifetime was made impossible by the control over the contract given to him, independent of her will. . . His control over the policy vas, subject to its items, as complete as if he himself had been the beneficiary." MIutual Benefit Life Ins. Co. v. Swett, 222 Fed. 200, $204-5$ (6th Cir. 1915); Davis v. Modern Industrial Banl, 279 N.Y. 405, 18 N.E.2d 639 (1939) ; Lemley v. McClure, 122 Pa. Sup. 225, 185 Atl. 578 (1936). The states which adhere to this view are listed, with citations, in $T a r$, op. cit. supra note 1, at 43-5; McCABAN, op. cit. supra note 9, at 233; 135 A.L.R. 1041 (1939).

43. Mutual Benefit Life Ins. Co. v. Swett, 222 Fed. 200 (6th Cir. 1915); Hiclss v. N.W. Mutual Life Ins. Co., 166 Ia. 532, 147 N.W. \&\&3 (1914) ; Elmore v. Continental Liie Ins. Co., $131 \mathrm{Kan} .355,291$ Pac. 755 (1930).

44. There is complete agreement among all courts that upon the death of the insured, the beneficiary's interest becomes completely fixed. White v. United States, 259 Fed. 855 (D.C. Cir. 1924); Irving Bank v. Alexander, 280 Pa. 466, 124 Atl. 634 (1924).

45. In West Virginia this result has been accomplished by statute W. Va. Laws 1947 , c. 102.

46. Rawls v. Penn MIutual Life Ins. Co., 253 Fed. 725 (5th Cir. 1918); Potter v. N.W. Mutual Life Ins. Co., 216 Ia. 799, 247 N.W. 669 (1933).

47. Merchants Bank v. Garrard, 158 Ga. 867, 124 S.E. 715 (1924); Shay v. Mrerchants Banking Trust Co., 335 Pa. 101, 6 A.2d 536 (1939); Atlantic دivt Life Ins. Co. v. Gannon, 179 Mass. 291, 60 N.E. 933 (1901) ; Mfente v. Townsend, 68 Arl: 391, 59 S.WW. 41 (1900).

Although the procedure set forth in the policy for such a change will not have been observed, this is held to be a formal defect which can be relied on only by the company. Equitable Life Ins. Co. v. Mitchell, 248 Ill. App. 401 (1927); Farmers' State Banls v. Kelley, 155 Ga. 733, 118 S.E. 197 (1923). It is usually held, further, that by interpleading 
however; any excess in the proceeds over the amount of the debt is paid to the beneficiary designated in the policy. ${ }^{48}$

Despite the background of the revocable beneficiary clause, courts in a substantial number of jurisdictions hold that the contract of insurance creates legally cognizable rights (still characterized as "vested" by some courts) in the beneficiary as well as the insured. ${ }^{49}$ They maintain that a strict interpretation of the policy shows that while the beneficiary's interest is conditional, it may be defeated only by the insured's exercise of his power to appoint a new beneficiary. ${ }^{50}$

This construction obviously leaves the bank-assignee in the precarious position of finding itself with no security for its loan if the beneficiary has not been displaced before the assignment. ${ }^{51}$ But since the beneficiary's

the rival claimants, the company waives its right to object. Taylor v. Southern Bank \& Trust Co., 227 Ala. 565, 151 So. 357 (1933) ; Bank of Belzoni v. Hodges, 132 Miss. 238, 96 So. 97 (1923).

But most courts consider an assignment and a change of beneficiary to be different. See, e.g., Mutual Benefit Life Ins. Co. v. Clark, 81 Cal. App. 546, 254 Pac. 306 (1927). The generally accepted rationalization for the distinction is that an assignment is the transfer by one of his right or interest in property to another, and rests on contract, while the power to change the beneficiary is the power to appoint. 2 COoLEY, op. cit. stlpra note 23 , at 1813. A functional analysis would appear to be more rewarding: a change of bencficiary usually relates to the security function and an assignment to the investment function.

48. Rattray v. Banks, 31 Ga. App. 589, 121 S.E. 516 (1924); First National Bank v. Security Mutual Life Ins. Co., 283 Mo. 336, 222 S.W. 832 (1920); Minnesota Mutual Life Ins. Co. v. Manthei, 189 S.W.2d 144 (Mo. App. 1945).

49. Typical of these decisions are Davis v. Acacia Mutual Life Ins. Co., 177 S.C. 321, 181 S.E. 12 (1935); Freund v. Freund, 218 Ill. 189, 75 N.E. 925 (1905); Sullivan v. Maroney, 77 N.J. Eq. 565, 78 Atl. 150 (1910). For a collection of cases supporting this rule, see TAIT, op. cit. supra note 1, at 33-5; 135 A.L.R. 1054-8 (1941).

50. Undoubtedly, one reason favoring the preservation of this view is the vague sentimental consideration which courts feel towards beneficiaries. Such a feeling can be gleaned from 'the following statement of the Kentucky Supreme Court: "Originally, the sole purpose of life insurance was to afford indemnity or protection to the family of the insured against poverty and want ... and for this object alone life insurance companics were primarily created and organized. But under the developing processes of industrial life and commercial expansion the object of life insurance has been extended, so as to ... allow [assignments] as security for loans to be employed in business adventures and commercial pursuits. Whether such extension of the use of life insurance is a departure from the philanthropic sentiment that gave it birth, is not for us to say; it is sufficient to know that it is recognized by the courts, and consequently to be respected and upheld within proper and legal bounds." Mutual Life Ins. Co. v. Twyman, $122 \mathrm{Ky} .513,525,92$ S.W. 335, 338 (1906).

51. Professor Grismore is one of the few commentators upholding this minority rute. Grismore, The Assignment of a Life Insurance Policy, 42 MrcH. L. Rev. 789 (1944). To hold otherwise, he asserts, is to make the right to the proceeds a property right which vests in the insured during his lifetime and passes to his designated beneficiary at death. But the rights derived from an insurance policy are contract rights; and a contract right vests as soon as the contract is signed. Id. at 798. The real question, however, is in what way may the beneficiary's right be defeated. Although he admits that the benti- 
interest may be defeated by a loan from the insurance company or by exercise of several other options in the policy, there seems little justification for maintaining it as against a bank-assignee who has lent money on the strength of the policy. The result of this anachronistic view is to force the insured to resort to the cumbersome and time-consuming process of changing the beneficiary before assigning a policy. And if for any reason this should be impractical, then he probably cannot secure a loan. ${ }^{52}$

By failing to make allowances for the dual nature of present day policies, this theory unduly restricts the number of operative events which may defeat the beneficiary's interest. The clause permitting the insured to change the beneficiary must be viewed in conjunction with the inclusion of surrender options in the policy whose purpose it was to enable the insured to get at the savings he invested in insurance. ${ }^{53}$ The event on which the beneficiary's interest rests should not be limited solely to the displacement of the beneficiary according to the strict procedure outlined in the policy; but should include the utilization by the insured of any of the investment possibilities available to him.

An alternative method of executing an effective assignment is to obtain the beneficiary's consent to the transaction, but if this is done there are numerous pitfalls against which the bank must guard. When the beneficiary is joined in the assignment, most courts consider him a real surety to the insured's obligation to the bank and, as such, he may be discharged on the same principles as a personal surety. ${ }^{54}$ Thus, if any change in the debtorcreditor relationship takes place of which he does not approve, his consent will be considered withdrawn and the bank's interest will become imperiled. Such a change might include an increase in the amount of the obligation, or

ciary's interest is conditional in modern life insurance policies, he puts forth no compelling reason for construing the contingency so narrowly.

52. "From an every day, practical standpoint it is desirable to hold that an assignee of a policy containing a clause permitting a change of beneficiary and an assignment of the policy secures a right in the proceeds of the policy superior to the rights of the named beneficiary. If an assignee, in the absence of the consent of the beneficiary, does not obtain such right it will be practically impossible for an insured to borrow on a folicy in time of need of financial aid in those cases where compliance with the form prescribed in the policy cannot be followed." Davis v. Mlodern Industrial Bank, 279 N.Y. 405, 414, 18 N.E.2d 639, 643 (1939).

53. "[These courts seem to] attach far too much importance to the insured's actual exercise of his right to change the beneficiary, where such right has specifically been reserved, and to grant too great a degree of ownership to the beneficiary named voluntarily and solely by the insured. They seem to fail to grasp the essentially dual character of the modern life insurance policy: that is, that while the insurance company contracts to pay a certain amount of money on the death of the insured, it also contracts to pay a certain amount of money on demand to the insured during his lifetime." TAIr, op. cit. stspro note 1 , at 35 .

54. Stevens v. First National Bank, 117 Ok1. 148, 245 Pac. 567 (1925); Fourth National Bank v. Woolfolk, 220 Ala. 344, 125 So. 217 (1929). Contra: Kendall v. Equitable Life Assur. Soc., 171 Miass. 568, 51 N.E. 464 (1S98). 
a time extension. ${ }^{55}$ Furthermore, under the statutes of a few states a wife cannot become surety for the obligations of her husband. ${ }^{68}$

Another difficulty, where consent of the beneficiary is obtained, concerns the competency of the beneficiary to release his interest. If a minor, the beneficiary may repudiate the pledge any time before reaching majority or within a reasonable time thereafter. ${ }^{57}$ And if the policy is payable to a trustee, the question arises as to whether the trustee is competent to join in the assignment. Since he does not act in his own right but as fiduciary for the beneficiary of the trust, he can make an effective transfer only if the power is conferred upon him by the trust agreement. ${ }^{58}$

Neither the insured nor the beneficiary gain from the uncertainty engendered by this doctrine. Where the beneficiary has successfully defeated the bank's claim to the proceeds, he is obviously a substantial gainer. But the class of beneficiaries as a whole has not been helped because most banks, to assure themselves the fullest protection, insist that any named beneficiary be displaced. ${ }^{59}$ Thus the beneficiary loses the right to any excess in the proceeds over the amount of the debt. Also lost are the special privileges which can be derived from insurance policies made payable to a named beneficiary. The most important of these is the statutory protection from the insured's creditors which is given to named beneficiaries..$^{60}$ Also lost is the protection of "spendthrift trust" provisions included in some state statutes which protect named beneficiaries from their own creditors where the insured has provided that the proceeds be paid in installments rather than a lump sum. ${ }^{61}$ To reinstate these lost privileges, it is becoming a common practice first to appoint the insured's estate as beneficiary and after the assignment has been accomplished to reappoint the original beneficiary subject to the rights of the assignee. ${ }^{62}$ While successful, if available, this pro-

55. See Bridge v. Connecticut Mut. Life Ins. Co., 167 Cal. 774, 781, 141 Pac. 375,379 (1914). The bank ordinarily attempts to void the requirement of obtaining the beneficiary's consent to these alterations by securing a waiver at the time of the assignment.

56. E.g., N.H. Laws 1942, c. 340, §2. There are similar statutes in Alabama, Gcorgia, Texas, and Wisconsin.

57. Hack v. Metz, 173 S.C. 413 , 176 S.E. 314 (1934).

58. In re Binder, 136 Ohio St. 26, 27 N.E.2d 939 (1940).

59. "Hence, the safest procedure for one lending on the security of the policy is to require the insured to make a formal change of beneficiary [to his own estate] and then assign." Patterson, Essentials of Insurance law 190 (1935).

60. E.g., N.Y. INs. LAW §166; S. C. Code $\S 7985$ (1942). For an analysis of the various types of statutes in force which protect designated beneficiaries against creditors, see Spencer, Rights of Creditors in Life Insurance, contained in McCAman, op. cilt. supra note 9 , at 43 et seq.

A further benefit accruing in favor of life insurance policies made payable to a designated beneficiary used to be a $\$ 40,000$ federal estate tax exemption. However, this was eliminated in 1942 in favor of a general exemption of $\$ 60,000$. See Ruslander, The Impact of Federal Estate Taxes on Life Insurance, 10 U. of PITT. L. Rev. 15, 24 (1948).

61. .E.g., N.Y. PERS. Prop. LAW $§ 15$.

62. One company, the Penn Mutual Life Insurance Company, requires that this be 
cedure is not always possible as several companies will not permit any change of beneficiary after an assignment has been made. ${ }^{63}$

\section{Writing the Confusion out of the Policy}

Although by slow judicial retreat the "vested interest" doctrine is being abandoned where the right to change the beneficiary is reserved, many insurance companies are speeding up the process by including in new policies a clause which completely eliminates the confusion. A typical provision is as follows:
"If the right to change the beneficiary has been reserved to the in- sured an assignment, release or surrender of this policy or any inter- est therein by the insured shall operate to the extent thereof to assign, release or surrender the interest of any and all beneficiaries hereunder." $6 s$

Thus the beneficiary's rights are subordinated to those of the assignee. Even in states which otherwise require a change of beneficiary or joinder to malse an assignment effective, courts have held that this clause in itself is sufficient to defeat the beneficiary's interest. ${ }^{65}$ If adopted by all companies, it would end the necessity of needless policy changes and establish from the outset the rights of the parties involved in the assignment. cs $^{\text {cs }}$

\section{Allocation of Rights Between the BANE AND the INSUREd}

Having made a loan with life insurance as collateral, a bank does not necessarily acquire complete control over the assigned policy. The extent of the assignee's rights has been limited by courts and insurers anxious to preserve the security potential which even pledged policies retain. But against this desire to protect the insured and the beneficiary must be weighed the necessity of assuring banks who loan money on the strength of insurance that the collateral will be liquid and have a readily ascertainable value."

done. They have adopted an assignment form which accomplishes all these steps by the inclusion of the following clause: "If this assignment is exccuted by the Insured alone ... then I, the Insured, for the purpose of subjecting to this assignment the designation of beneficiary in force immediately preceding this assignment, (a) hereby change the baneficiary and designate as beneficiary of the policy at the time of this assignment my executors or administrators; and (b) reinstate, effective immediately after this assignment, the designation of beneficiary in force immediately preceding the change of beneficiary made by Paragraph (3a) above."

63. If the loan is secured by several items of collateral including the insurance policy, this procedure will work to the disadvantage of the beneficiary. Since the teneficiary is entirely displaced to the extent of the loan, she will not be entitled to be sultrogated to the other collateral, Kash v. Kash, 260 Ky. 508, \&6 S.W.2d 273 (1935), a right which she otherwise would have had. Smith v. Coleman, 184 Va. 259, 35 S.E.2d 107 (1945) ; Barbin v. Moore, 85 N.H. 362, 159 Atl. 409 (1932).

64. Clause used by Phoenix MIutual Life Insurance Company.

65. Fisher \& Co. v. Phoenix MIutual Life Ins. Co., 15 Tenn. App. 502 (1932).

66. See Grismore, supra note 51 , at $\$ 02$.

67. See Holland, supra note 2 , at 21 . 
Although the assignment agreement between the borrower and the bank may be general in nature, due to the quest for certainty the more usual practice is to allocate control specifically over the various options in the policy. More recently, the emphasis has been on the development of a standard form drawn up by representatives from both the banking and insurance fields. The insurers have sought to protect borrowers from arbitrary terms which banks, being in the stronger bargaining position, might dictate. And banks, anxious to standardize procedures since the volume of assignments has become so large, have been willing to accept compromise provisions. ${ }^{63}$

\section{The Assignment Agreement}

Generally speaking, the measure of the bank's rights is the terms of the agreement it enters into with the borrower. Consequently, banks have constantly sought to devise an assignment form under which the insurer would grant them exclusive control over all options affecting the proceeds and cash reserve value of the policy. Yet they want the insurer to continue to assume responsibility for the disposition of surpluses to which they, as assignees, are not entitled. ${ }^{6}$

In an effort to gain access to the policyholder's options, some banks denominate the assignment form "absolute" and secure a transfer of "all right, title and interest." 70 But this usually avails them little, as courts have always held it necessary to look behind the form and see if the assignment was in reality collateral. ${ }^{71}$ And if the bank exceeds its rights as collateral assignee, it is liable for illegal conversion..$^{22}$ Therefore, most insurers, even when the absolute form is used, insist upon the assignee's proving existence of the debt and default, and in addition, of ten make checks payable to the joint order of the assignee and the insured or beneficiary. ${ }^{73}$ On the other hand, some insurers treat such assignments as absolute in fact, paying the full amount of the proceeds to the bank-assignee, thereby making it responsi-

68. "The bank must realize that the liquidation of the type of security evidenced by a life insurance policy as collateral can be accomplished only through dealing with the in surance company issuing the policy. It is therefore always necessary for the bank as assignee to meet the requirements of life insurance companies in respect to the assignment of their policies:" Collins, supra note 7, at 93.

69. See Comments on Form No. 10, supra note 20.

70. See, e.g., Exhibit 4, A Bank Form of Absolute Assigmment, contained in TArt, op. cit. supra note 1, at 92; see Brown v. New York Life Ins. Co., 22 F. Supp. 82 (W.D.S.C. 1938) (transfer of "all dividend, benefit and advantage").

71. New York Life Ins. Co. v. Rees, 19 F.2d 781 (8th Cir. 1926); Allen v. Home National Bank, 120 Conn. 306, 180 At1. 498 (1935).

72. See, e.g., Toplitz v. Bauer, 161 N.Y. 325, 55 N.E. 1059 (1900).

Likewise, the insurance company will be held liable for illegal conversion if, knowing that the assignment is collateral, it allows the assignee to exercise complete control. But the fact that the assignment is to a bank is not sufficient in itself to put the company on notice that it is collateral rather than absolute as indicated on its face. New York Life Ins. Co. v. Brown, 99 F.2d 199 (4th Cir. 1938).

73. See Dechert, supra note 9, at 38. 
ble for the proper distribution of any surpluses. ${ }^{74}$ Furthermore, many courts and insurers hold that when there is no mention of transfer to the bank of control over the specific options in the policy, the bank's right is limited to an interest in the proceeds. ${ }^{75}$

Since this form of assignment has proven generally unsatisfactory, most banks have drawn up forms by which the insured specifically transfers his control over the policy's options. In addition, these forms usually include a waiver by the borrower of all of his legal rights. ${ }^{70}$ Nevertheless, when a banl:devised form is used, many insurance companies still refuse to deal exclusively with the assignee, and courts, for their part, interpret the waiver provisions very strictly. $\pi$

As the volume of life insurance assigned as collateral increased, banls felt the necessity of establishing with more certainty the rights which insurers would recognize as exclusively theirs. And insurance companies wished for a standard form which would eliminate the burden of interpreting the wide variety of forms with which they were being presented. ${ }^{\text {is }}$ To accomplish these ends, the Bank Management Commission of the American Bankers Association collaborated on a form with a committee of the Association of Life Insurance Counsel in 1938. The insurers assumed the duty of protecting their policyholders since they felt that in the long run their interests were inseparably bound up with the welfare of the insured. 30 Their primary efforts were directed towards assuring the borrower a reasonable opportunity to redeem the policy and establishing a strict limitation on the liabilities for which the policies were pledged. ${ }^{\natural 3}$ As a result of negotiations,

74. Mítual Benefit Life Ins. Co. v. First National Bank, 25 Ky. L. Rep. 172, 74 S.W. 1066 (1903) ; Binkley v. Jarvis, 102 Ill. App. 59 (1902).

A particularly troublesome problem will arise if the insured has elected some form of installment payments since the bank may be required to pay out the surplus in accordance with the plan.

75. Grossman v. Lindemann, 67 Misc. 437, 123 N.X. Supp. 108 (1910); Flatonia State Bank v. Southwestern Life Insurance Co., 127 S.W.2d 1SS (Tex. Civ. App. 1939); 7 COOLEY, op. cit. supra note 23 , at 6527.

76. See, e.g., Snyder v. Home Life Ins. Co., 328 Pa. 424, 195 Atl. $\$ 95$ (1938).

77. See, e.g., Toplitz v. Bauer, 161 N.Y. 325, 55 N.E. 1059 (1900) (time extension constitutes waiver of right to surrender policy without notice); Bailey v. American Deposit \& Loan Co., 52 App. Div. 402; 65 N.Y. Supp. 330 (1900), aff d 165 N.Y. 672, 59 N.E. 1118 (1901) (same).

78. Handy, Why Uniformity in Collateral Assignment Blanks, 5 Ass': of Life Ins. Counser Procendngs 307 (1932).

79. "[In regard to standard assignment forms] the insured can have no fear as to the form of the instrument, because the insurance company will not only protect itself but will also throw around the assignment every possible safeguard for its policy holders. .. . Companies cannot exist without keeping policy holders; the insurer must be more or less paternalistic." Webster, stipra note 7, at 78.

80. "[A notice provision] was one of the primary points of the insurance companies in our original negotiations. They claim, and with good reason, that life insurance is different from other forms of collateral, and that the insured should be given a reasonable opportunity to redeem. They wanted this, and a specific limitation on liabilities for which 
these committees developed a standard form which is used by 75 per cent of the banks making loans on life insurance. ${ }^{81}$ Most of the remaining loans are made on collateral forms supplied by the insurance company so that in these cases the borrower is at least as well protected as if the ABA form were used. ${ }^{82}$

\section{Cash Surrender and Loan Options}

A bank is most concerned with acquiring control over the cash surrender and loan options in the policy. Without the right to liquidate the policy on default, it may find itself with nothing better than a long-term investment on its hands..$^{83}$ But from the insured's point of view there is a counterbalancing consideration. To him the policy may be worth far more than the cash surrender value. This depends on such factors as his health, whether he is insurable, and whether he can obtain the same type of policy to replace the one assigned. ${ }^{84}$

These conflicting demands have resulted in a split of authority as to the assignee's prerogative in those cases where the assignment does not specifically transfer the right. Under the general rule the assignee has the right to surrender the policy and receive its cash surrender value upon default in payment of the indebtedness. ${ }^{85}$ However, some courts deny the bank this right, holding that in the absence of a distinct provision, the assignment

the policies were pledged, and a covenant on the part of the bank-assignce that it would pay any amounts it received over and above the indebtedness secured to the persons properly entitled thereto (this last really not necessary; banks liable for this whether they agree to be in writing or not), as necessary conditions to make it possible for insurance companies to deal exclusively with banks in settlement." Communication to the YALE LAW Journal from Robert C. Tait, member of the Committee on Revision of Life Insurance Assignment Form No. 10 of the Bank Management Commission, American Bankers Association.

81. Figures were obtained by the American Bankers Association several years ago by the use of a mailed questionnaire. Returns were not too high, but assuming the percentage distribution of those who answered obtained to all banks making loans on life insurance, the following figures were arrived at: $75 \%$ of the banks making loans on lifo insurance used the ABA standard form and about $25 \%$ (mostly small banks) used whatever collateral form the insurance companies supplied. Of the $75 \%$ who used the $\mathrm{ABA}$ form, $95 \%$ used it without modification or supplemental agreement. However, since the time of the questionnaire, the ABA has done a great deal of educational work and it is the surmise of the Bank Management Commission that the form is now used by $20 \%$ of the banks making loans on life insurance. Ibid.

82. Some thirteen or fourteen life insurance companies have adopted the $A B A$ form as their company form. Ibid.

83. The bank has the right to pay the premiums and keep the policy alive if tho insured fails to do so, (see note 104 infra), but it faces the danger of advancing a sum which, added to the original debt, will exceed the proceeds of the policy.

84. See notes 20 and 21 supra.

85. Bank of Idana v. Illinois Life Ins. Co., 135 Kan. 129, 9 P.2d 629 (1932); McGimpsey v. Security Bldg. \& Loan Ass'n, 10 N.J. Misc. 17, 157 Atl. 441 (Sup. Ct. 1931); cases collected in 114 A.L.R. 778 (1938). 
confers "only the right to collect, not to sell or surrender." $\varepsilon^{3}$ And in these instances, before the policy can be liquidated, the assignee must either foreclose the insured's interest in a separate proceeding ${ }^{87}$ or cut off his interest by a public sale after notice has been given to the insured. ${ }^{83}$

But out of this disharmony there seems to be emerging a uniform rule which does justice to the positions of both borrowers and lenders: the collateral assignee may exercise the surrender options, but only if he has first given the insured notice of the intended surrender which is sufficient to afford him a reasonable opportunity to redeem the pledge. ${ }^{\Xi 2}$ The insured is as well protected by simple notice as he is by the requirement of legal foreclosure in a separate proceeding. And the right to surrender without notice is not necessary to insure the bank of an adequate safeguard against the borrower's consuming the policy's reserve by not paying the premiums.:

This middle ground is the one adopted in the ABA form. The bank cannot exercise the options upon default until twenty days after it has notified the borrower of its intention to exercise the right.01 The notice requirement seems appropriate. By the laws of most states an insurance company making a loan against a life insurance policy cannot cancel the policy until written notice has been given to the policyholder.92 In negotiating the requirement for banks, the companies felt that considering the almost identical nature of the transaction, if public policy required notice in one instance, it should be compelled in the other. In most cases if the borrower wishes to save the policy he will be allowed to obtain a policy loan from the company..$^{93}$ The twenty day notice provision affords him ample time to resort to this or other methods of refinancing the loan.

86. Grossman v. Lindemann, 67 Misc. 437, 123 N.Y. Supp. 108 (1910); Flatonia State Bank v. Southwestern Life Ins. Co., 127 S.W.2d 188 (Tex. Civ. App. 1939).

87. Missouri State Life Insurance Co. v. Langreder, 87 F.2d 586 (7th Cir. 1937); Mutual Life Ins. Co. v. Twyman, $122 \mathrm{Ky} .513,92 \mathrm{~S} . \mathrm{W}$. 335 (1906).

8s. Dungan v. MIutual Benefit Life Ins. Co., 46 IId. 469 (1877); MIanton v. Robinson, 19 R.I. 405, 37 Atl. 8 (1896).

89. One commentator after analyzing the cases concluded that in virtually every instance in which notice was given, the bank's right to surrender was upheld, whereas in virtually every case in which it definitely appeared that the pledgee neglected to inform the insured of the attempted action, the surrender was held wrongful or inoperative. Note, 48 YaLe L.J. 315, 319 (1938). In Wilson v. Prudential Ins. Co., 123 Pa. Super. 364, 187 Atl. 251 (1936), the court makes a similar analysis of previously decided eases. (Id. at 253.) But it must be remembered that while any sort of notice will satisfy most courts, a few seem to insist on judicial foreclosure. See notes $\$ 7$ and $8 S$ sespro.

90. Upon non-payment of the premiums, one of the automatic non-forfeiture provisions goes into effect. If extended insurance is called for, this will eat away the policy's eash value. See p. 759 infra.

91. American Bankers Ass'n Form No. 10, §E.2 (Reprinted as Appesiors A infra). The notice stipulated is a letter, mailed by first class mail, to the borrower at the address last supplied to the bank.

92. E.g., N.Y. Irs. LAw $\$ 151$.

93. This practice is encouraged by the Bank Management Commission. Further- 


\section{Limiting the Liability Secured}

Through the medium of their standard note and pledge agreements, banks have customarily sought to acquire a broad lien over all property coming into their possession. But insurers have always strenuously objected to so-called "dragnet clauses" ${ }^{94}$ since they feel that life insurance should not be used as security for any obligation for which it was not consciously and intentionally pledged. This point of controversy has proved extremely difficult to compromise and was resolved in the $A B A$ form only by resorting to language which has an inconclusive meaning. The assignment is made to pertain to any liability "either now existing or that may hereafter arise in the ordinary course of business." ${ }^{95}$ It was hoped at least to prevent the application of the policy to any outside indebtedness. If properly construed, this clause should limit the coverage to the obligations of a maker, endorser, or guarantor of any bond, note, bill or other instrument payable to the assignee, the obligation of a discount endorser when the assignee is the discounting bank, and any other transaction which it was the assignor's clear intention to secure by the pledge..$^{96}$

Some banks attempt to nullify this provision, and the one requiring twenty days notice before surrender, by using a supplementary waiver in connection with the form. ${ }^{97}$ But to counteract these waivers, the drafter's of the ABA form inserted a stipulation that if the provisions of the assignment and the provisions of the note or other evidence of liability are in conflict, the assignment shall prevail.98 This stipulation was intended to negate dragnet coverage clauses and waivers of notice. ${ }^{93}$

more, banks are urged to resort to policy loans to satisfy the indebtedness whencver possible, rather than to surrender the policy for its cash value. Comments on Form No. 10, stipra note 20.

94. For an example of a dragnet clause, see Bancroft v. Granite Savings Bank and Trust Co., 114 Vt. 336, 44 A.2d 542 (1945) (assignment stipulated as follows: "The above specified collateral to be holden for the payment of this note and any other notes, debts or liabilities now due or to become due or that may be hereafter contracted to said Bank ....").

95. ABA Form No. 10, $\$$ D.

96. The controlling factor is the intent of the parties. Potter Title \& Trust Co. v, Berkshire Life Ins. Co., 156 Pa. Super. 1, 39 A.2d 268 (1944). Where there is any doubt on this matter, the bank can bring the questioned liability under the assignment by sccuring a letter from the assignor setting forth his intention to have the liability sccured by the assignment.

97. The number of banks resorting to this practice has been calculated at $5 \%$ at most. See note 81 sipra.

98. ABA Form No. $10, \S \mathrm{J}$.

99. There have been no cases in which the effect of this stipulation has becn adjudicated. It is believed that it will prove effective against conflicting provisions in the ustual bank collateral notes, particularly the waiver of notice clauses usually provided in stich notes. But its efficacy is doubted against the terms of any supplemental agreement, particularly if the agreement specifically refers to the assignment and note and was exccutcd subsequent to the other instruments. Communication to the YALE LAw JourNAL from 


\section{Automatic Non-forfeiture Provisions}

In the event the insured stops paying the premiums, one of the two nonforfeiture options which are included in most life insurance policies automatically takes effect: ${ }^{100}$ (1) the purchase of as much paid-up insurance as the cash value of the policy will permit; or (2) use of the cash value of the policy to pay premiums on the face amount on an extended term basis. ${ }^{101}$ To one who holds life insurance as collateral there is a great deal of difference between these options. When a policy lapses and automatically converts into a reduced amount of paid-up insurance, the cash value remains exactly the same as it was under the premium paying policy. In fact, it gradually increases as interest accrues. But under the extended term insurance provision, the cash value immediately begins to decrease and is ultimately exhausted. The assignee under this provision has no protection except the death benefits and these can only be realized if the insured dies before the cash value runs out. To insure the maintenance of the collateral's value, the $\mathrm{ABA}$ form allocates the right of election to the bank. ${ }^{102}$

\section{Right to Reimbursement for Premium Payments}

Maintaining premium payments on pledged policies is one of the bank's most troublesome problems. ${ }^{103}$ Failure of the insured to pay the premiums will result in activation of one of the non-forfeiture provisions. And while the bank certainly does not want the reserve to be decimated, neither does it desire to see the face value of the policy reduced, especially if the amount of the loan exceeds the reserve value of the policy.

In the event the borrower does not pay the premiums, the bank has two alternatives if it wishes to maintain the full value of the policy. It may apply for a premium loan from the insurance company or it may pay the full amount of the premium itself. When either course is followed, courts have allowed the bank to add any amounts expended, including interest accrued, to the amount of the indebtedness regardless of whether there has been a specific provision to that effect in the assignment agreement. ${ }^{204}$

Robert C. Tait, member of the Committee on Revision of Life Insurance Assignment Form No. 10 of the Bank MFanagement Commission, American Bankers Association.

100. VANCE, op. cit. supra note 16 , at 282.

101. Either of these alternatives may be required by statute. See, c.g., N.Y. Irss. Law

\$208. The latter alternative is required in Missouri. MIo. REv. ST.4T. \$5852 (1939).

102. ABA Form No. 10, $\$$ B.5.

103. The policyholder pays the premium directly to the company, and since the usual custom is to wait until the last minute before making payment, the bank may be unable to determine whether there is going to be a default on the premium payment. The safest method for the bank to handle the problem is to require the insured to present his premium receipt within a given number of days before the grace period for payment expires. Holland, supra note 2 , at 25-6.

104. Des Moines Savings Bank v. Kennedy, 142 Ia. 27?, 120 N.W. 742 (1909); MicNeil v. Cobb, 186 App. Div. 177, 173 N.Y. Supp. 865 (1919). The ABA form follows this rale. ABA Form No. 10, $\$$. 


\section{Dividend Options}

Nearly all policies in participating companies grant the insured several options as to the application of dividends. The standard options are: (1) to have them paid in cash to the insured; (2) to apply them automatically in reduction of premiums; (3) to allow them to accumulate with interest as dividend deposits; and (4) to apply them to the purchase of additional paid-up insurance.

The general attitude of insurance companies is that these dividends are the insured's and should remain in his control unless he defaults on the loan. Therefore, when an assignment is silent as to the rights conveyed to the assignee in respect to these options, most companies will refuse the assignee's request to change the manner in which the dividends are to be applied unless they first give their consent. ${ }^{105}$ But to gain their other objectives, the insurers gave control over these options to the banks in the ABA form. However, until the insurer is notified otherwise, the original choice remains in force. ${ }^{106}$

\section{Disability Income}

Where no specific provision is made in the assignment agreement, most companies insist that any disability income benefits belong to the insured and do not pass under the assignment. ${ }^{107}$ But many of the older policies, particularly those written before World War I, provided a form of disability benefit which constituted a claim on the policy itself and under which the policy immediately matured just as it would in the event of death. Under such a contract the insurance company paid to the insured the principal and income installments out of the proceeds of the policy. To protect banks against the diminution of the collateral made possible by these policies, the ABA form limits the right of the insured to disability income payable in cash which does not reduce the amount of the insurance. ${ }^{108}$

\section{Miscellaneous Rights Not Transferred to the Bank}

Two of the options in any policy are solely under the control of the insured. They are the right to change the beneficiary and the right to choose among the optional modes of settlement, i.e., whether the policy will be paid in a lump sum or in installments. ${ }^{109}$

If the insured has chosen an installment option, the bank is usually careful to see that it is not required to accept payment of the indebtedness in like manner. Some insurers preclude this possibility by drawing up a new beneficiary agreement which provides that in the event a collateral assignment

105. TAIT, op. cit. supra note 1 , at 55 .

106. ABA Form No. 10, \& B.4.

107. TAIT, op.cit.supra note 1 , at 75 .

108. ABA Form No. 10, § C.1.

109. Id., \$§ C.2, 3 . 
is outstanding at the time the policy becomes a claim, the assignee will be paid in one sum and the balance will be applied by the company to the installment payments elected by the insured. Other companies refuse to permit the insured to elect installment payments after or subject to an assignment. ${ }^{110}$

\section{CoNCLUSION}

The assignment of life insurance as collateral security represents one of the more recent steps in the process of wresting control of life insurance from the beneficiary and establishing it in the insured. Some courts, resisting this encroachment on the ancient supremacy of the security function, have cast restrictions on assignability. But with recognition of the fact that modern life insurance has a dual function-investment in addition to securitymost courts allow the insured to assign without first defeating the beneficiary's interest. While more recent policies contain a clause giving an assignee precedence over the beneficiary in order to eliminate confusion which has resulted from divergent judicial views, the uncertainty remains with respect to the great number of unmatured policies presently held which do not have this provision. In light of the historical development of modern insurance policies and the probable intent of the insured, the majority view seems preferable. Furthermore, it benefits all parties to the assignment: the bank's interest is made more secure, the beneficiary is in no danger of being displaced and remains entitled to any surplus in the policy's value over the debt, and the insured is afforded a broader opportunity to capitalize his insurance in time of need.

Limitation of the assignee's control over policies which have been pledged seems, in the long run, a more rewarding way to protect the insured and the beneficiary than does the maintenance of technicalities in the assignment procedure. Courts and insurers have afforded policyholders substantial, though haphazard, protection in this respect. More precise and systematic safeguards have been gained by use of the standard assignment form sponsored by the $A B A,{ }^{111}$ since insurance companies in negotiating the provisions of this form with banks wielded their extensive bargaining power in the insured's behalf. Under this form the borrower is assured of reasonably fair terms when he assigns his life insurance as collateral. And by clarifying

110. See Report of Special Committe on Reziew of Forms of Collatcral Assignments of Life Insurance Policies, Proceednigs of Assoc. of LmF INs. Counsel 3-7 (1941).

111. In addition to its work in constantly checling to see that the form meets the needs of the parties, the Bank Management Commission does extensive edueational vorl: to convince local banks of the fairness and utility of the form. The most vigorous objection has been to the provision requiring twenty days notice before surrender, but it is believed that this opposition has been substantially broken down. Communication to YALE LAv Journal from Robert C. Tait, member of the Committee on Revision of Life Insurance Assignment Form No. 10 of the Bank Management Commission, American Banlsers Assuciation. 
the rights of all parties affected by the transaction, this standard form has considerably aided in eliminating the uncertainty and confusion which have, thus far, characterized the law with respect to the assignment of life insurance.

\section{ApPEndix A}

Form No. 10-LIFE INSURANCE ASSIGNMENT
Form Approved By

Bank Management Commission American Bankers Association

\section{ASSIGNMENT OF LIFE INSURANCE POLICY AS COLLATERAL}

A. FOR VALUE RECEIVED the undersigned hereby assign, transfer and set over to

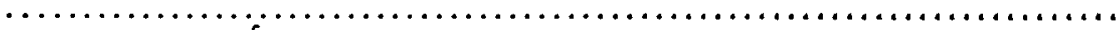
$\ldots \ldots \ldots \ldots \ldots \ldots$ of $\ldots \ldots \ldots \ldots \ldots \ldots \ldots \ldots \ldots \ldots \ldots \ldots \ldots \ldots \ldots \ldots \ldots \ldots \ldots \ldots \ldots$ its successors and assigns, (herein called the "Assignee") Policy No... . . . . . . . . . . . . .

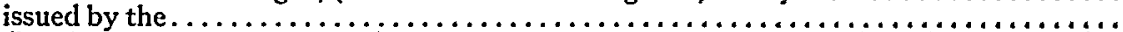
(herein called the "Insurer") and any supplementary contracts issued in connection therewith (said policy and contracts being herein called the "Policy"), upon the life of

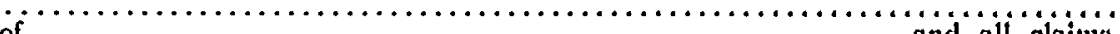
options, privileges, rights, title and interest therein and thereunder (except as provided in Paragraph $C$ hereof), subject to all the terms and conditions of the Policy and to all superior liens, if any, which the Insurer may have against the Policy. The undersigned by this instrument jointly and severally agree and the Assignee by the acceptance of this assignment agrees to the conditions and provisions herein set forth.

B. It is expressly agreed that, without detracting from the generality of the foregoing, the following specific rights are included in this assignment and pass by virtue hercof:

1. The sole right to collect from the Insurer the net proceeds of the Policy whicn it becomes a claim by death or maturity;

2. The sole right to surrender the Policy and receive the surrender value thereof at any time provided by the terms of the Policy and at such other times as the Insurer may allow;

3. The sole right to obtain one or more loans or advances on the Policy, either from the Insurer or, at any time, from other persons, and to pledge or assign the Policy as security for such loans or advances;

4. The sole right to collect and receive all distributions or shares of surplus, dividend deposits or additions to the Policy now or hereaf ter made or apportioned thereto, and to exercise any and all options contained in the Policy with respect theretoi provided, that unless and until the Assignee shall notify the Insurer in writing to the contrary, the distributions or shares of surplus, dividend deposits and additions shall continue on the plan in force at the time of this assignment; and

5. The sole right to exercise all nonforfeiture rights permitted by the terms of tho Pollcy or allowed by the Insurer and to receive all benefits and advantages derived there. from.

C. It is expressly agreed that the following specific rights, so long as the Policy has not been surrendered, are reserved and excluded from this assignment and do not pass by virtue hereof :

1. The right to collect from the Insurer any disability benefit payable in cash that does not reduce the amount of insurance;

2. The right to designate and change the beneficiary;

3. The right to elect any optional mode of settlement permitted by the Policy or allowed by the Insurer; but the reservation of these rights shall in no way impair the right of the Assignee to surrender the Policy completely with all its incidents or impair any other right of the Assignee hereunder, and any designation or change of benteficiary or election of a mode of settlement shall be made subject to this assignment and to the rights of the Assignee hereunder.

D. This assignment is made and the Policy is to be held as collateral security for any and all liabilities of the undersigned, or any of them, to the Assignee, either now existing or that may hereafter arise in the ordinary course of business between any of the undersigned and the Assignee (all of which liabilities secured or to become secured are herein called "Liabilities"). 
E. The Assignee covenants and agrees with the undersigned as follows:

1. That any balance of sums received hereunder from the Insurer remaining after payment of the then existing Liabilities, matured or unmatured, shall be paid by the Assignee to the persons entitled thereto under the terms of the Poliey had this ascignment not been executed;

2. That the Assignee will not exercise either the right to surrender the Policy or (except for the purpose of paying premiums) the right to obtain policy loans from the Insurer, until there has been default in any of the Liabilities or a failure to pay any premium when due, nor until twenty days after the Assignee shall have mailed, by first-elass mail, to the undersigned at the addresses last supplied in writing to the Acaignee specifically referring to this assignment, notice of intention to exercise such right; and

3. That the Assignee will upon request forward without unreaconable delay to the Insurer the Policy for endorsement of any designation or change of beneficiary or any election of an optional mode of settlement.

F. The Insurer is hereby authorized to recognize the Assignee's claims to rights hereunder without investigating the reason for any action taken by the Assignce, or the validity or the amount of the Liabilities or the existence of any default therein, or the giving of any notice under Paragraph E (2) above or otherwise, or the application to be made by the Assignee of any amounts to be paid to the Assignee. The sole signature of the Assignee shall be sufficient for the exercise of any rights under the Policy assigned hereby and the sole receipt of the Assignee for any sums received shall be a full discharge and release therefor to the Insurer. Chechs for all or any part of the sums payable under the Policy and assigned herein, shall be drawn to the exclusive order of the Assignee if, when, and in such amounts as may be, requested by the Assignee.

G. The Assignee shall be under no obligation to pay any premium, or the principal of or interest on any loans or advances on the Policy whether or not obtained by the Assignce, or any other charges on the Policy, but any such amounts so paid by the Ascignee from its own funds, shall become a part of the Liabilities hereby secured, shall be due immediately, and shall draw interest at a rate fixed by the Assignee from time to time not exceeding $6 \%$ per annum.

H. The exercise of any right, option, privilege or power given herein to the Acsignee shall be at the option of the Assignee, but (except as restricted by Paragraph E (2) above) the Assignee may exercise any such right, option, privilege or power without notice to, or assent by, or affecting the liability of, or releasing any interest hereby assigned by the undersigned, or any of them.

I. The Assignee may take or release other security, may release any party primarily or secondarily liable for any of the Liabilities, may grant extensions, renewals or indulgences with respect to the Liabilities, or may apply to the Liabilities in such order as the Assignee shall determine, the proceeds of the Policy hereby assigned or any amount received on account of the Policy by the exercise of any right permitted under this ascignment, without resorting or regard to other security.

J. In the event of any conflict between the provisions of this assignment and provisions of the note or other evidence of any Liability, with respect to the Policy or rights of collateral security therein, the provisions of this assignment shall prevail.

K. Each of the undersigned declares that no preceedings in banliruptey are pending against him and that his property is not subject to any assignment for the benefit of creditors.

Signed and sealed this $\ldots \ldots \ldots \ldots \ldots$ day of $\ldots \ldots \ldots \ldots \ldots \ldots \ldots, \ldots, \ldots$

Wituess

Witiness

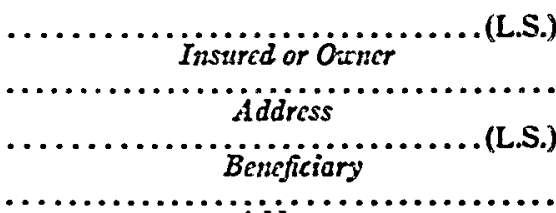

Address 